\begin{tabular}{c|c|c}
\hline \hline Vol. 251: 1-14, 2003 & MARINE ECOLOGY PROGRESS SERIES \\
Mar Ecol Prog Ser & Published April 11 \\
\hline
\end{tabular}

\title{
Convection and primary production in winter
}

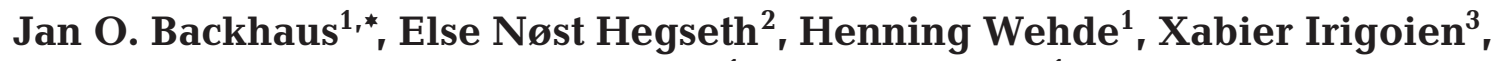 \\ Kerstin Hatten ${ }^{1}$, Kai Logemann ${ }^{1}$ \\ ${ }^{1}$ Institute of Oceanography, University of Hamburg, Troplowitzstr. 7, 22529 Hamburg, Germany
${ }^{2}$ The Norwegian College of Fisheries Science, University of Tromsø, 9037 Tromsø, Norway
${ }^{3}$ Technological Institute for Fisheries and Food AZTI, Herrera Kaia, Portualde z/g, 20110 Pasaia, Spain
}

\begin{abstract}
We present observations of temperature, salinity and phytoplankton from late winter of 1999 obtained along a meridional transect running from 52 to $72^{\circ} \mathrm{N}$ through the northern North Atlantic and Norwegian Sea. The field work was conducted with the intention to find evidence for a postulated relationship between convection and primary production in the open ocean in winter. In the investigated area, convection ventilates water masses in a deep mixed layer which may cover several hundreds of meters, depending on atmospheric forcing and stratification. Inspired by the results of a coupled phytoplankton convection model, we postulated that sinking phytoplankton from the seasonal thermocline in autumn is dispersed within the mixed layer by vertical orbital motions and turbulence induced by convection. Orbital motions allow intermittent visits of plankton to the euphotic layer from much deeper depths. Hence, convection distributes the chance of plankton receiving light over the entire mixed layer. This supports production and allows compensation of losses due to sinking. We hypothesised that a winter stock of living phytoplankton in the open ocean would always coincide with the deep mixed layer formed by convection, irrespective of its depth. Indeed, along the entire meridional transect, living phytoplankton was found within the layer, whereas only marginal amounts or virtually no phytoplankton existed beneath it. The layer extent varied between 300 and $800 \mathrm{~m}$. In the northern North Atlantic, average concentrations of chlorophyll a (as a measure of phytoplankton biomass) in the mixed layer were about $0.3 \mathrm{mg} \mathrm{m}^{-3}$, and 0.6 $\mathrm{mg} \mathrm{m}^{-3}$ in the Norwegian Sea. We concluded that this winter stock forms the inoculum for a spring production in the open ocean.
\end{abstract}

KEY WORDS: Primary production $\cdot$ Winter $\cdot$ Convection $\cdot$ Vertical orbital motions

\section{INTRODUCTION}

In the North Atlantic and Nordic Seas, phytoplankton investigations show a serious sampling bias. This is due to most investigations focussing on the spring bloom and summer conditions, leaving a gap in knowledge with regards to winter. The winter season, however, is important for the pre-conditioning of a spring bloom. Earlier phytoplankton investigations in the North Atlantic have often been restricted to the coastal areas around Iceland and the Faeroes (Paulsen 1904, 1918, Steemann Nielsen 1935, 1943). Continuous plankton recorder measurements provide data about species composition of large phytoplankton near the sea surface in the North Atlantic dating back to 1948

*Email: backhaus@dkrz.de
(Robinson 1970, Reid 1977). The North Atlantic bloom experiment (NABE) of 1989 in the open Atlantic (e.g. Ducklow \& Harris 1993) provided detailed knowledge about the spring bloom. The Norwegian Sea has been subjected to extensive phytoplankton studies, which initially focussed on species composition. Later, studies with a more ecological point of view were introduced. Several investigations were carried out in the 1950s, and were generally restricted to May and June (Paasche 1960, Ramsfjell 1960, Paasche \& Rom 1962). Halldal (1953) was first to perform a year-round investigation of phytoplankton from Weathership M (see our Fig. 1 for its position), and much later, studies with a comparable focus followed (Brettum 1969, Dale et al. 1999). 
Primary production models (on both global and regional scale) generally rely on the assumption that there is, despite remarkable sinking rates (Smayda 1970, von Bodungen et al. 1981, Billett et al. 1983, Platt et al. 1983, Passow 1991), always a small though (apparently) sufficiently large phytoplankton population available in late winter to initiate a spring bloom (Platt et al. 1990, Anderson, 1993). The predictions of these models suggest that this assumption is valid. However, in view of known sinking rates of phytoplankton, a sound explanation for the existence of a winter stock is still missing.

Recently, Huisman et al. $(1999,2002)$ presented a theoretical concept, i.e. a 1-dimensional model including a source term (i.e. light-dependent production), turbulent mixing, and a sinking rate of phytoplankton. Investigating the influence of turbulence and depth of mixing on blooms of sinking plankton, Huisman et al. (2002) report a critical range, i.e. both large depth and large turbulence levels, where, according to their model, no blooms would occur. The field observations we present here contradict these results. In the discussion we will explain the discrepancy between the theory and our observations due to an important physical process that was not considered by Huisman et al. (2002), namely convection.

It was only during the past decade that convection in physical oceanography, in contrast to meteorology, received any interest. Probably the most spectacular topic in this regard is the deep sinking of water masses in high latitudes (see overview by Marshall \& Schott 1999) which drives the global conveyor belt circulation. Conservation of mass, however, requires that any sinking must be accompanied by an upward motion. Dynamics of convection can, therefore, be visualised by vertical orbital cells which occupy a convective mixed layer (CML). Up- and downward motions of convection cells are linked by horizontal motions at both upper and lower perimeters of orbits. Separation scales in convective cells are well correlated. Both laboratory (Turner 1973) and modelling studies (Kämpf \& Backhaus 1998) report an aspect ratio of about 2.5:1 (horizontal vs vertical scale). Thus, a CML extending over $1000 \mathrm{~m}$ would imply horizontal scales of convection that are smaller than $3 \mathrm{~km}$. This explains why it is so difficult to observe convection in the open ocean directly, and its vertical motions in particular. The existence of convection can, however, be diagnosed from the 'straightness' of profiles of both temperature and salinity within the CML. This straightness, i.e. the neutral stability of the water column, is caused by the turbulent mixing induced by convection. In a neutrally stratified water column, only little energy is needed to drive vertical motions. Hence, orbital motions of convection, that is, up- and downward currents with a zero net motion, can displace water masses and also particles (i.e. plankton) over distances in the order of hundreds of meters. Typically, vertical velocities in developed convection measure 0.1 and $0.05 \mathrm{~m} \mathrm{~s}^{-1}$ for down-, and upward motions, respectively (Marshall \& Schott 1999, Backhaus \& Kämpf 1999).

In the literature dealing with phytoplankton and the properties of its physical habitat, 'turbulent mixing' is often used to explain vertical transport. Townsend et al. (1994), for instance, considered the role of 'deep wind mixing' in winter with regard to plankton dynamics. However, any wind induced mixing on a rotating earth is confined to the Ekman layer which, in mid-latitudes, has a typical thickness of approximately $50 \mathrm{~m}$. The same rotational constraint holds for Ekman pumping. Thus, in the open ocean (i.e. excluding upwelling regions), convection, in contrast to vertical turbulent mixing (e.g. mixing caused by winds and/or surface waves, tides etc.), is the only turbulent process which can account for a significant vertical transport.

In this paper we pose the same question as Huisman et al. (2002) in their article entitled: 'How do sinking phytoplankton species manage to persist?' By extrapolating knowledge about the physics of convection (Turner 1973, Backhaus \& Wehde 1997, Backhaus et al. 1997, Kämpf \& Backhaus 1998, 1999, Backhaus \& Kämpf 1999, Marshall \& Schott 1999), and about convection and plankton dynamics in shallow seas (Hegseth et al. 1995, Backhaus et al. 1999, Wehde \& Backhaus 2000, Wehde 2001), we arrived at the following hypothesis: Sinking phytoplankton originating from the seasonal thermocline in autumn is dispersed within a convective mixed layer by both motions and turbulence induced by convection. Motions in vertical orbital cells, typical for convection, allow visits of plankton to the euphotic layer from much deeper depths. This supports a production which allows a compensation of losses due to sinking and turbulent mixing. Our hypothesis implies that a winter stock of living phytoplankton in the open ocean, if it were to exist, would always coincide with the well mixed layer that is formed and affected by convection, irrespective of its depth. In extrapolating this picture towards spring, we postulated that a production of phytoplankton in spring is initiated by the winter stock, which is maintained by convection.

By focussing on the under-investigated winter season, we here report and interpret winter observations from the northern North Atlantic and Norwegian Sea which were carried out with the intention of testing our hypothesis of an existing link between convection and primary production in the deep open ocean in winter. 


\section{MATERIALS AND METHODS}

Strategy of field work. Two cruises (Cruises 176 and 178) with RV 'Valdivia' were conducted in late winter and early spring of 1999 (26 February to 20 March, and 8 to 26 of April, respectively). Both cruises together, cum granu salis, formed a meridional transect running north from about 52 to $72^{\circ} \mathrm{N}$, thereby meeting largely similar conditions with regard to light and forcing of convection characteristic of late winter. The cruise track (Fig. 1) followed the 'Talweg' of the deep ocean basins, thus avoiding submarine ridges or other topographic structures which might have induced local vertical motions (i.e. topographic upwelling). The second cruise (Cruise 178) went from the Faeroe Islands towards the Greenland Sea. However, in the context of this paper we only consider data taken south of $72^{\circ} \mathrm{N}$, i.e. south of the northern margin of the Norwegian Sea. Our data was documented in a technical report (Backhaus et al. 2000).

Hydrography and meteorology. A CTD with a rosette sampler measured continuous profiles of fluorescence, temperature, and conductivity, i.e. salinity. Temperature readings (protected and unprotected thermometers) and salinity samples from each CTD

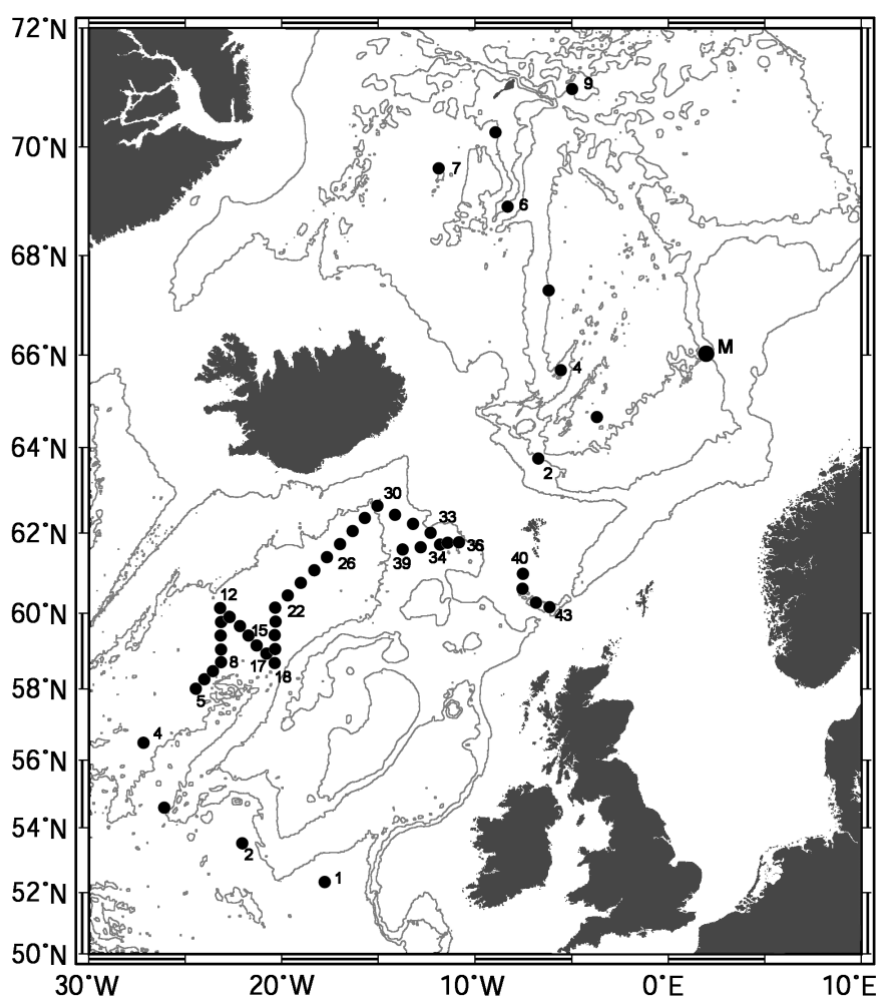

Fig. 1. Cruise track (•) and stations covered by RV 'Valdivia' (Cruises 176 and 178) in the northern North Atlantic, Icelandic and Norwegian Sea (note: to the north of the Faeroe Islands, numbering of stations belongs to Cruise 178). Position of Weathership $\mathrm{M}$ is indicated cast served to calibrate the CTD. The final calibration of all data complied with standards set by the international world ocean circulation experiment (WOCE). Along-track surface temperature and salinity were measured with a thermosalinograph mounted in the ship's moon-pool at a depth of ca. $6 \mathrm{~m}$. The ship's meteorological station continuously monitored atmospheric parameters which, together with sea surface temperature, were used to compute estimates of the net heat and radiation budget of the ocean surface. Wet and dry air temperatures were measured by hand every $3 \mathrm{~h}$ for estimation of latent heat fluxes.

Biology. Phytoplankton distribution in the water masses was measured as vertical profiles of fluorescence down to depths well below the deep thermocline. Samples for chl a analysis from 12 to 15 depths were collected in the rosette sampler within the CML and below. Analyses were performed fluorometrically in duplicates on GF/F filters with methanol as the extracting agent (Holm-Hansen \& Riemann 1978). Additionally, all samples were fractionated by pre-filtering water through a $20 \mu \mathrm{m}$ net before analysis.

Samples for cell enumeration and identification were collected by filling all water bottles in the rosette sampler at one depth (4 to 5 depths per station, within and below the CML) and straining the water through a $25 \mu \mathrm{m}$ plankton net. This way, $170 \mathrm{l}$ of sea water were concentrated into a $250 \mathrm{ml}$ sample. All samples were preserved with neutralised Formalin (final concentration $4 \%$ ). Later, 2 and $50 \mathrm{ml}$ subsamples were counted in an inverted microscope (Utermöhl 1931, 1958).

Live net samples were tested for viability in 2 ways. In all samples, in vivo fluorescence with and without the electron transport blocking herbicide DCMU ( $F_{\mathrm{DCMU}}$ and $F$, respectively) was measured (Roy \& Legendre 1979). Live samples from selected stations were brought to the laboratory in Tromsö and grown at in situ temperatures and moderate irradiance (60 to $70 \mu \mathrm{mol} \mathrm{m} \mathrm{m}^{-2} \mathrm{~s}^{-1}$ ).

\section{RESULTS}

\section{Hydrographic and meteorological observations}

Our estimates of the along-track net heat-fluxes (Fig. 2) show that the ocean, on average, was losing heat, thus driving convection in the weakly stratified water column in late winter. Only during daytime was the ocean gaining heat, with diurnal variations being more pronounced during the second cruise, i.e. in the Norwegian Sea. These conditions are typical for late winter. Amplitudes of diurnal heat-flux oscillations were, on average, in the order of $200 \mathrm{~W} \mathrm{~m}^{2}$ (Fig. 2). When applied to the observed stratification and mete- 

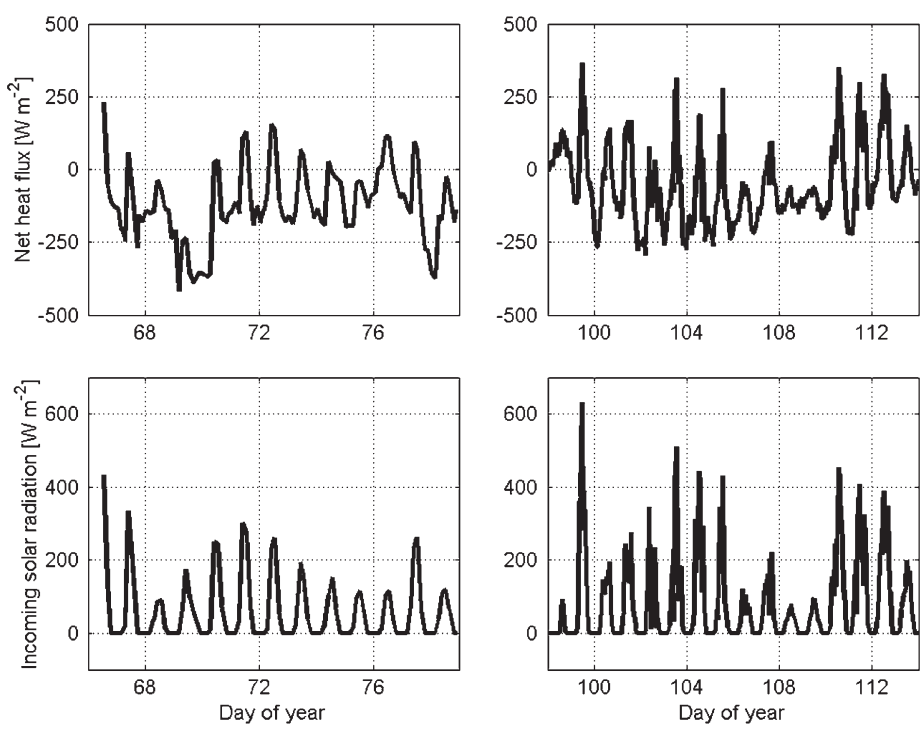

Fig. 2. Estimates of the along-track net oceanic heat-flux $\left(\mathrm{W} \mathrm{m}^{-2}\right)$ (top panels) and incoming solar radiation ( $\mathrm{W} \mathrm{m}^{-2}$ ) (bottom panels) derived from onboard meteorological observations in the Icelandic Basin (left panels) and Norwegian Sea (right panels). The heat-flux comprises long- and short-wave radiation, and turbulent fluxes of sensible and latent heat (negative values indicate ocean cooling)

orological forcing conditions, our convection model (Backhaus et al. 1999) predicted that convection would not cease during daytime but slowly spin down until it received another forcing during the night. For the first cruise the estimated incoming solar radiation (Fig. 2) shows amplitudes typically well below $200 \mathrm{~W} \mathrm{~m}^{2}$. In the Norwegian Sea average amplitudes were still below $200 \mathrm{~W} \mathrm{~m}^{2}$, but a higher variability, with peaks well above $400 \mathrm{~W} \mathrm{~m}^{2}$, prevailed.

The close coincidence between chl $a$ and the vertical extent of the CML which we observed along the entire transect (Backhaus et al. 2000) is exemplified by a selection of chl $a$ and temperature/salinity (TS) profiles from the northern North Atlantic, i.e. the Icelandic Basin (Fig. 3). Small variations in TS profiles within the CML were accompanied by large variations of chl a (Fig. 3a). The penetration depth of convection varied considerably, in particular in the Icelandic Basin where particularly large differences were found between 2 stations separated by only $30 \mathrm{n}$ miles (Fig. 3b,c). Straight and upright profiles of TS indicate convection. This was rarely seen in profiles of chl a. An exception is shown in Fig. 3d. The deepest penetration of convection (Fig. 3e) was found in the northern Icelandic Basin.

South of the Iceland-Faeroe Ridge, along-track convection depths deepened from ca. 300 to $400 \mathrm{~m}$ in the south to $800 \mathrm{~m}$ in the north. North of the Ridge, i.e. in the Icelandic and Norwegian Sea, the meridional gradient in convection depth was less steep, and pene- tration of convection was confined to values around $300 \mathrm{~m}$. We refer to Fig. 4 where these gradients also appear in the along-track vertical distribution of chl a. Convection depths (Fig. 4) are separated by a sharp transition at about $63^{\circ} \mathrm{N}$ which indicates the water mass boundary of the sub-polar front situated at the Iceland-Faeroe Ridge.

\section{Frequency of convection orbits}

For an understanding of the role of convection with regard to production it would be convenient to have a simple measure of relevant time scales induced by the dynamics of convection. The aspect ratio and the typical velocities of a developed convection (see 'Introduction') allow us to derive an estimate for the period of convection orbits. That is, the return rate of plankton to the sea surface after a full completion of an orbit. We approximate an orbit as a rectangle. The dimensions of the rectangle, according to the aspect ratio, can be scaled by $H_{\mathrm{CML}}$, i.e. the actual depth of the CML. Then the width of the rectangle is $2.5 H_{\mathrm{CML}}$, and its height is $H_{\mathrm{CML}}$. We assume that the horizontal flow which links up- and downward flows has the same magnitude as upward convection velocities, i.e. $0.05 \mathrm{~m} \mathrm{~s}^{-1}$. Compared to typical downward velocities with a magnitude of $0.1 \mathrm{~m} \mathrm{~s}^{-1}$, this is a conservative estimate which also complies with typical values we derived from our convection model (Backhaus et al. 1999). In further assuming that typical convection velocities do not depend on the depth of the CML, which, cum granu salis, complies with the results of our convection model, we arrive at an orbital time scale $T_{\text {orb }}$ by adding the individual time scales of the 4 sides of the rectangle. Time scales are given by dividing a distance by its respective velocity:

$$
T_{\text {orb }}=H_{\mathrm{CML}} / 0.1+2\left(2.5 H_{\mathrm{CML}}\right) / 0.05+H_{\mathrm{CML}} / 0.05
$$

Here the middle term stands for the time scale needed for a water parcel to cover the distance of the width of the rectangle at both upper and lower perimeters of an orbit. The first and last term represent the time scale for a down- and upward motion, respectively. The above time scale $T_{\text {orb }}$ (in seconds) is then given by:

$$
T_{\text {orb }}=6.5 H_{\mathrm{CML}} / 0.05=1.3 H_{\mathrm{CML}} \times 10^{2}
$$

With some rounding we arrive at a simple approximation for the period of convection orbits $T_{\text {orb }}$ as a function of the CML depth $H_{\mathrm{CML}}$, given in hours:

$$
T_{\text {orb }} \sim H_{\mathrm{CML}} / 30
$$

Thus, according to this rule of thumb, with $H_{\mathrm{CML}}=$ $600 \mathrm{~m}$, for instance, the completion of an orbit would need $<1$ d, i.e. about 20 h. 

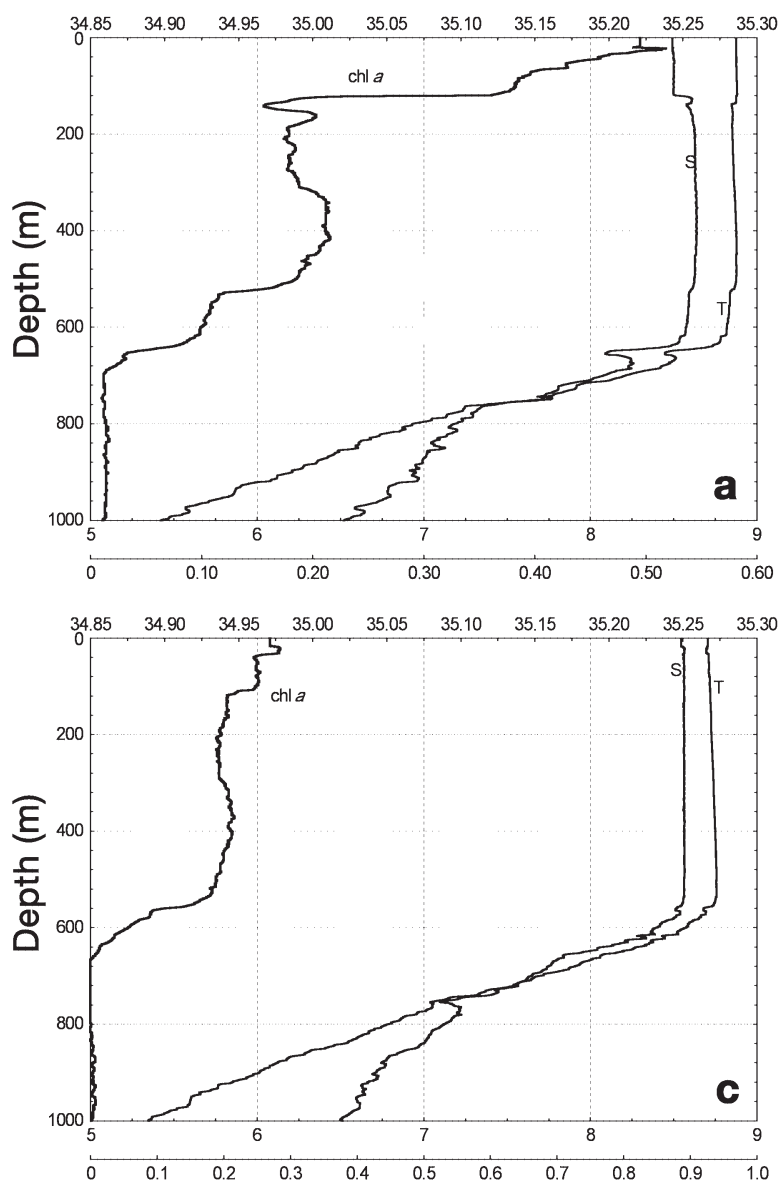

Fig. 3. Selected CTD profiles of temperature and salinity (TS) and $\mathrm{chl}$ a from the Icelandic Basin. Upper bottom axis: potential temperature $\left({ }^{\circ} \mathrm{C}\right)$; lower bottom axis: $\mathrm{chl} \mathrm{a}\left(\mathrm{mg} \mathrm{m}^{-3}\right)$; top axis: salinity. (a) Station 7; (b) Station 15; (c) Station 17; (d) Station 22; (e) Station 34. For location of stations, see Fig. 1

Similarly, again as a function of the CML depth only, we can derive an approximate time scale $T_{\exp }$ for the potential exposure of plankton to light during one orbit, if light were available. This time scale can, cum granu salis, be defined as the time needed to cover the horizontal distance between vertical motions at the upper perimeter of an orbit. That is, the expected time ( $T_{\exp }$ ) to cover one width of the rectangle is $T_{\exp }$ $2.5 \mathrm{H}_{\mathrm{CML}} / 0.05$, yielding an orbital exposure time, given in seconds, of $T_{\exp } \sim 50 \mathrm{H}_{\mathrm{CML}}$. According to this estimate, for the example of a $600 \mathrm{~m}$ deep $\mathrm{CML}$, any cell in the mixed water column would spend about 8 out of $20 \mathrm{~h}$ in the upper perimeter of an orbit.

These formulae were derived by assuming a simplified geometry, and velocities of fully developed convection. In view of the considerable variability of both convection and forcing conditions, the formulae
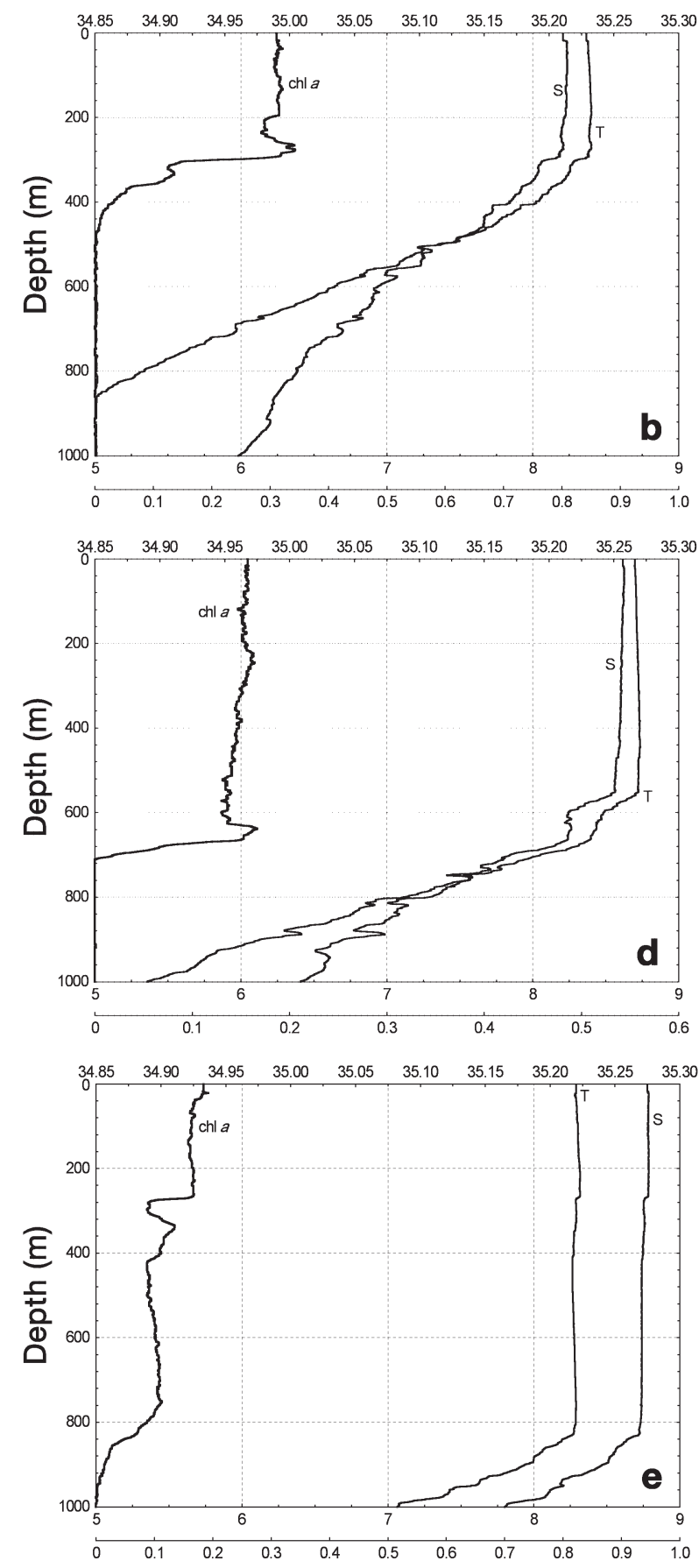

should be considered with care, and applied as crude estimates only. However, conveniently, the only input parameter needed is the actual depth of the CML which can be inferred from field data. We realise that the frequency of orbits is inversely correlated with the CML depth. The same holds for the exposure to light. Thus, shallower CMLs would have a higher frequency of orbits, but also shorter exposure times. 


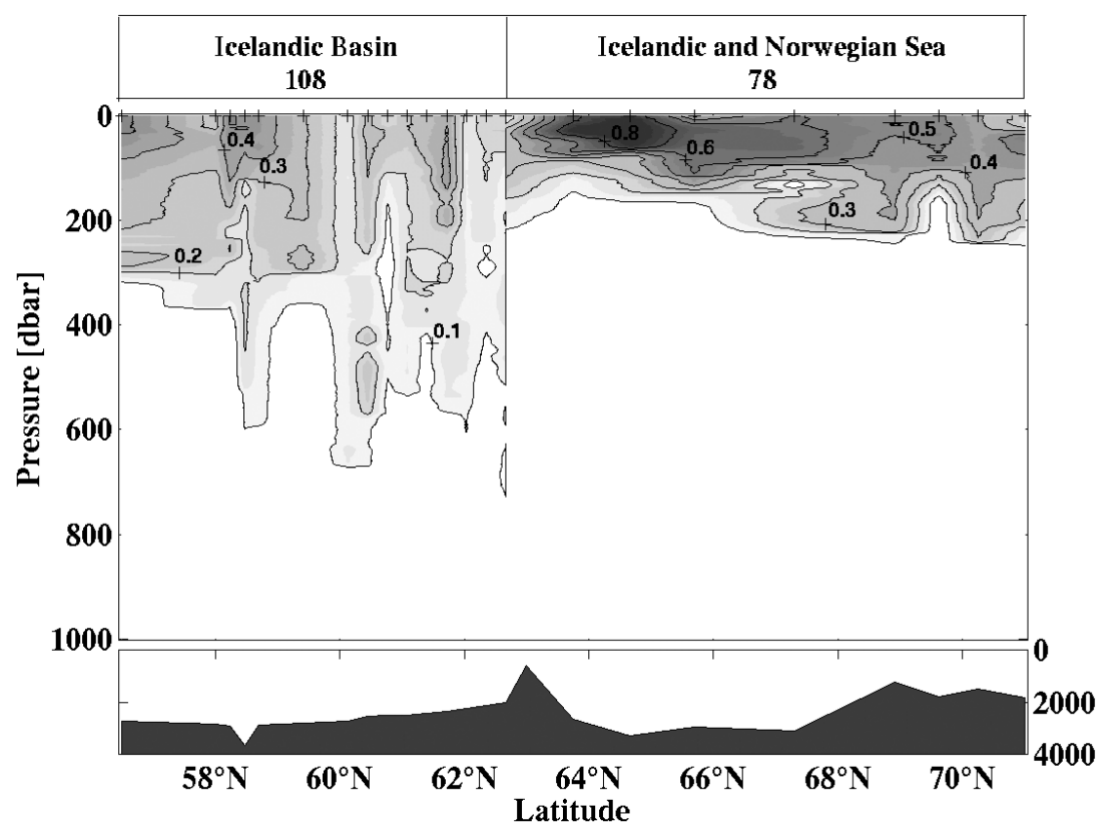

Fig. 4. Along-track contours of CTD chl a concentrations $\left(\mathrm{mg} \mathrm{m}^{-3}\right)$ versus depth. Numbers in upper boxes indicate vertically integrated biomass $\left(\mathrm{mg} \mathrm{m}^{-2}\right)$ averaged over the respective sea region. Lower panel: soundings (m) and latitude along cruise track

By comparing the orbital time scale $T_{\text {orb }}$ with our model results (Wehde 2001) we found that our thumbrule slightly underestimated the orbital period. An orbit might actually take more time because, in our estimate, we have neglected the role of turbulence which adds a chaotic element to orbits. Moreover, the assumed velocities, when applied in a simplified geometry, might actually result in an overestimation as compared to a more realistic case. However, the time scale given by $T_{\text {orb }}$ is in the right order of magnitude.

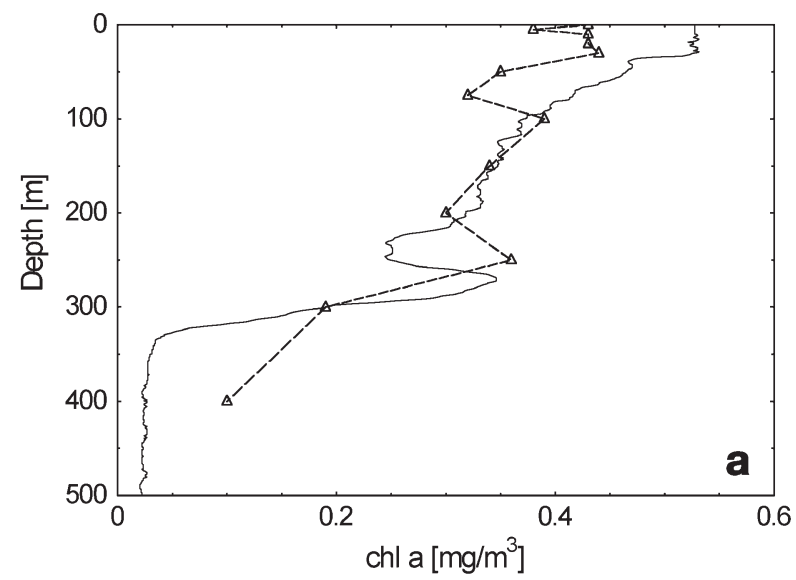

\section{Biological observations}

Extracted concentrations of $\mathrm{chl} a$, and their vertical distributions, corresponded well with the profiles of the fluorescence sensor mounted in the CTD (Fig. 5). For all data a correlation of 0.79 between sensor data and extracted chl a was found. The majority of the data scatter appeared in the surface layers. Below the penetration depth of convection, biomass was always insignificant, and a sharp decline in biomass was observed at the lower base of the CML. This gradient appeared to be situated slightly above the thermocline (cf. Fig. 3). Even at the site of deepest penetration of convection (i.e. about $800 \mathrm{~m}$ ), elevated chl a concentrations were found within the CML (Fig. 3e). The along-track vertically integrated chl a content (Fig. 4) was higher in the North Atlantic than in the Norwegian Sea (on average: 108 vs $78 \mathrm{mg} \mathrm{m}^{-2}$ ) noting, however, that higher average chl $a$ concentrations appeared in the Norwegian Sea $\left(0.60\right.$ vs $\left.0.28 \mathrm{mg} \mathrm{m}^{-3}\right)$.

The $<20 \mu \mathrm{m}$ cell fraction, mainly flagellates, predominated in the phytoplankton populations. The fraction of large cells ( $>20 \mu \mathrm{m}$ ) made up 8 to $15 \%$ of the chl $a$ in the North Atlantic, and only 3 to $6 \%$ in the Icelandic and Norwegian Sea. Since this fraction normally contains the major spring bloom species (Halldal 1953, Paasche \& Rom 1962, Brettum 1969), a concentrated sample would reveal species occurring in very low numbers, but nevertheless as possible inocula. At least 70 species have been identified in the North Atlantic so far, and about 50 in the Norwegian Sea. Diatoms made up about $70 \%$

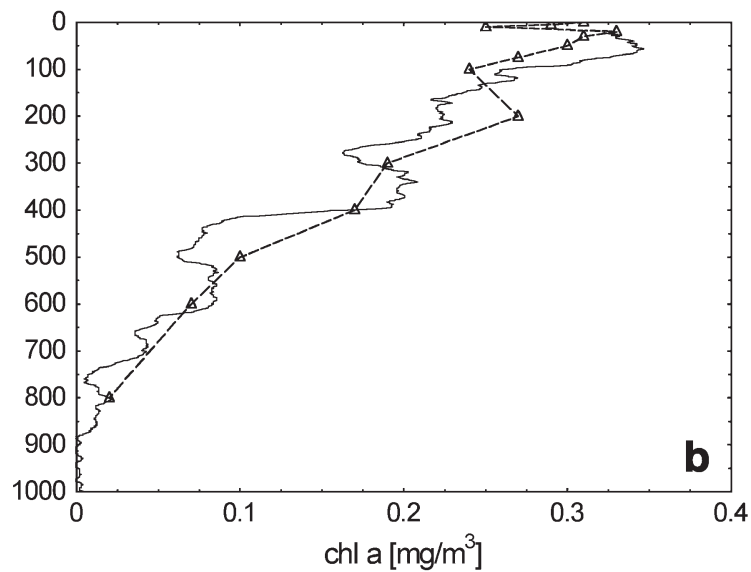

Fig. 5. Comparison of calibrated CTD-fluorescence with chl a from water samples ( $\Delta---\Delta)$ at (a) Stn 4 and (b) Stn 26 in the Icelandic Basin. For location of stations see Fig. 1 
of the large cells in the North Atlantic, and $60 \%$ in the Norwegian Sea. The remaining species consisted of dinoflagellates and silicoflagellates. Dominating species south of the Iceland-Faeroe Ridge were mainly diatoms such as Chaetoceros laciniosus, Proboscia alata, Thalassionema frauenfeldii and Thalassiosira spp., in addition to Dictyoca speculum which occurred in high numbers in the entire area. In the Norwegian Sea phytoplankton populations were considerably less rich in composition, and dominating species were C. laciniosus, Chaetoceros concavicornis, Fragilariopsis spp. (oceanica and cylindrus), Thalassiosira spp. and various Protoperidinium spp. D. speculum was frequently found, though in lower numbers than in the North Atlantic.

The total number of the large cell fraction was

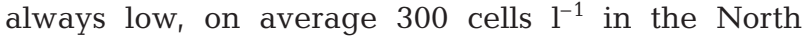
Atlantic and only 63 cells l$^{-1}$ in the Norwegian Sea, in spite of the later sampling period. The distribution pattern of large cells closely resembled the chl a distribution (Fig. 4), and large cells exhibited fluorescence ratios $\left(F_{\mathrm{DCMU}}: F\right)$ in the range of 2 to 3 during daytime, and well below 2 during the night. Below the $\mathrm{CML}$, a few cells and/or empty frustules were occasionally found, mainly the largest and heaviest diatoms of the Thalassiosira and Coscinodiscus genera. However, detritus always occurred in high amounts below the CML compared to within the CML. At all stations in both areas a population of copepodids of the cyclopoid Oncaea rested below the CML. Zooplankton species within the CML consisted of small animals. Nauplii, mainly a mixture of Oithona spp. and small calanoid copepods (Microcalanus, Paracalanus) constituted 50 to $75 \%$ of the populations, the rest consisted of copepodids, dominated by Oithona spp. Most animals were evenly distributed within the CML. Zooplankton populations were larger in the North Atlantic, aver aging 2000 ind. $\mathrm{m}^{-3}$, compared with 1300 ind. $\mathrm{m}^{-3}$ in the Norwegian Sea. In the latter, in April, a few copepods and nauplii of Calanus finmarchicus were also observed.

\section{DISCUSSION}

\section{Introductory remark}

In reflecting our hypothesis and the field data presented here we concluded that our attempt to test the hypothesis was successful. Our observations prove the presence of a winter stock of living phytoplankton in the deep mixed layer affected by convection. This finding supports the postulated existence of an intricate relationship between convection and primary production, considered below in further detail. The existence of convection in the regions investigated is without question (McCartney \& Talley 1982, van Aken \&
Becker 1996, Marshall \& Schott 1999), and also confirmed by our observations. Presently, however, we cannot prove with in situ observations that plankton is moved up and down in the deep mixed layer to receive light, which is the most important facet in the picture we are attempting to draw. We can only postulate this transport, and its influence on production, from simulations with our coupled phytoplankton-convection model (Backhaus et al. 1999, Wehde \& Backhaus 2000, Wehde 2001). Since we are stepping on new ground, our interpretations, and conclusions presented below, admittedly contain some speculation. We attempt, in a step by step manner, to describe and interpret findings that we derived from our field observations and model results. Together they form pieces of a puzzle which ultimately fit together to form a new picture about primary production in the open ocean in winter.

\section{Winter production supported by convection}

Active convection induces high levels of turbulence which rapidly homogenise water mass properties within the CML. Very straight and upright profiles of TS (Fig. 3) are indicative of the neutral stability of the water column caused by the severe convective mixing. The same would eventually hold for passive tracers dispersed by convection. However, a vertical homogenisation of plankton rarely occurred, as opposed to water mass properties. The majority of profiles from both cruises (Backhaus et al. 2000) showed that concentrations of phytoplankton increased towards the sea surface (Fig. 3). The only conclusion we could draw from this finding was that production had caused the observed distribution in biomass. A winter production was already postulated long ago by Marshall \& Orr (1928). Viability tests showing high $F_{\mathrm{DCMU}}: F$ ratios confirmed that algae were indeed actively photosynthesising (Roy \& Legendre 1979). Elevated chl a concentrations (Fig. 3) occupy depths well below the euphotic zone which we explain by the vertical transport of convection orbits (Backhaus et al. 1999, Wehde \& Backhaus 2000). They account for repeated and intermittent visits of plankton to the euphotic layer (Wehde 2001) but they also remove plankton from this layer. While production only occurs within the euphotic layer, convection advects and mixes, i.e. re-distributes the result of this production to depths well beneath the euphotic layer. We next discuss this issue in a theoretical context.

\section{Theory and observations, the missing link}

We return to the theory of Huisman et al. (1999, 2002) because it appears to reflect presently accepted 
knowledge about the relationship between primary production and its physical environment to which we want to add an important, yet missing, physical process. Huisman et al. (2002) considered a competition between light-dependent production and losses due to sinking and 'turbulent drainage'. Their model predicts a production of phytoplankton only if sinking rates and turbulent mixing do not exceed a critical value. Turbulent mixing re-distributes plankton in the production region, i.e. the euphotic layer. But turbulence also mixes, i.e. 'drains', plankton towards depths beyond the euphotic layer. In the following context it is important to note that plankton, according to present knowledge, is considered as lost (in terms of production) once it has left the euphotic layer. While moderate rates of turbulence favour production (Huisman et al. 2002), large rates favour turbulent drainage, i.e. loss. For conditions in winter, i.e. high turbulence and weak production due to low light, the competition would inevitably be biased towards higher losses. Therefore, the Huisman model cannot predict that a living stock of plankton exist in a deep layer during winter conditions in the open ocean. Our observations (Fig. 4), however, demonstrate that such a stock does exist. How can this discrepancy be explained?

In the competition between light-dependent production and losses due to sinking and 'turbulent drainage', an important ingredient is missing: convection. We explain below why the competition would change in favour of production, if transport due to convective orbital motions was considered (Backhaus et al. 1999, Wehde \& Backhaus 2000, Wehde 2001). In this context, however, 2 issues which either have a negative or no influence on the competition need to be mentioned first: (1) Sinking plankton, when exposed to orbital motions with zero net vertical flow, would eventually be lost from the CML because convection cannot retain sinking plankton in the CML but only retard losses due to sinking; (2) the high and deep reaching turbulence induced by convection would enhance losses from the CML due to turbulent drainage.

\section{The key issue}

The important issue with regard to production is that orbital motions, in a statistical sense, distribute chances of plankton receiving light over the entire CML. Hence, all cells of a winter stock residing in the CML are potentially available to sustain production because all have a chance to be transported to the euphotic layer, that is, to receive light. Therefore, in an integral sense, the entire CML can be considered a production region, that is, a 'virtual euphotic layer'. We note that the (real) euphotic layer in winter would only occupy a marginal fraction of the CML. Hence, with the same (though low) concentration, the CML in winter contains a significantly larger amount of biomass than the euphotic layer. We concluded that convection supports production in winter by enlarging the effective production region potentially available to sustain growth. That is how phytoplankton is able to win the winter competition. Obviously, a slowly producing winter stock (Fig. 4) residing in a deep virtual euphotic layer (i.e. our CML) can compensate losses due to sinking and turbulent drainage.

\section{Spring production}

We extrapolate our knowledge of winter conditions, i.e. the observed coincidence of phytoplankton and convection depth, towards spring, and towards the onset of a seasonal thermocline. At some time in spring, i.e. with increasing heating of the ocean, the CML will become a seasonal thermocline as schematised in Fig. 6a. It is now near at hand to conclude that production in spring is initiated by the winter stock maintained by convection as already found for shallow seas (Backhaus et al. 1999). However, in view of an existing production in winter, which undergoes a gradual transition to spring conditions (Fig. 6a), we do not require the existence of a seasonal thermocline for a 'spring bloom'. In fact, Dale et al. (1999) and Backhaus et al. (1999) report spring production that commenced well before a seasonal thermocline had been established. Facing the extreme variability of both physical and ecological environmental conditions in spring, there is no distinct signal which sets the onset of a 'spring bloom' in a clearly defined way. To support this statement we refer to the spring observations at Weathership M, as presented below (Fig. 7).

\section{Winter versus spring biomass}

Phytoplankton in winter is dispersed in a deep mixed layer by convection. This dilution results in low concentrations. Average concentrations of plankton (Fig. 4) along our transect (Fig. 1) were indeed low. Yet, in terms of integrated biomass, the CML in winter (Fig. 4) contained quite a large stock of living plankton. Surprisingly, the biomass of winter and spring stocks in the regions investigated appear to be of the same order of magnitude. The stock observed in the Icelandic Basin (Fig. 4), for instance, would yield a concentration

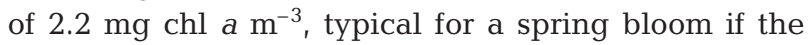

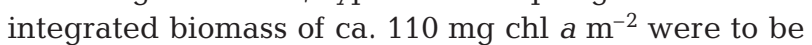
condensed into a hypothetical surface layer with $50 \mathrm{~m}$ thickness. Moreover, the biomass (78 $\mathrm{mg}$ chl a $\mathrm{m}^{-2}$ ) 

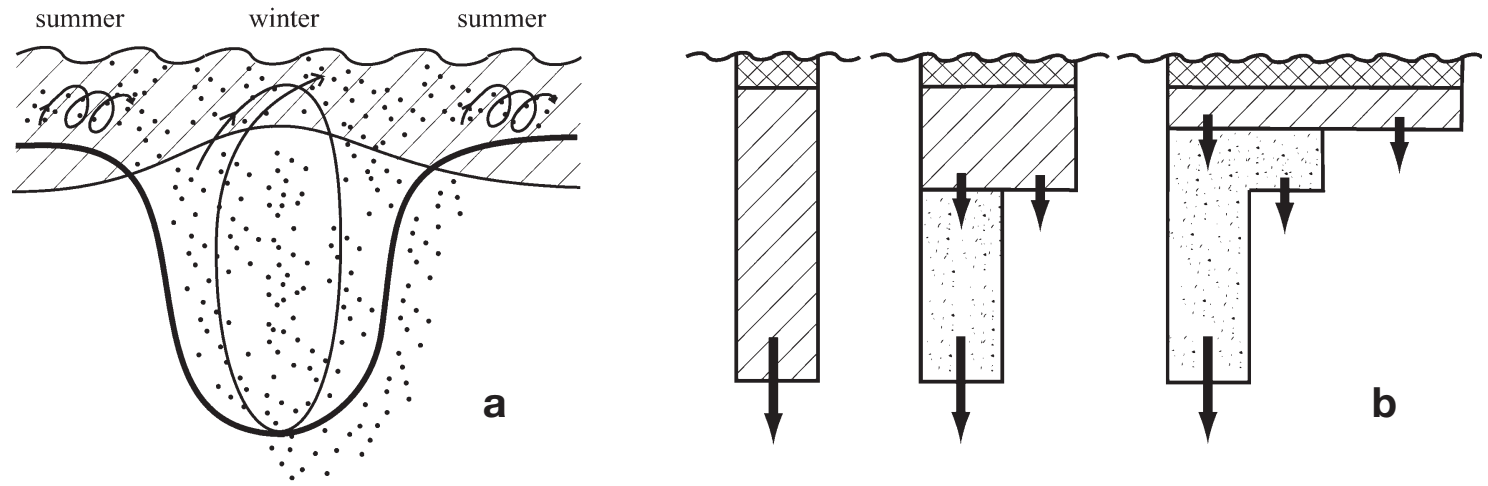

Fig. 6. (a) Annual evolution of plankton (dots) dispersed within the convective mixed layer (CML) by turbulence and orbital motions induced by convection. Looped arrows indicate orbits of convection. The CML in winter (thick line) includes the euphotic layer (diagonally striped), the reduced depth of which depicts low irradiance. Losses of plankton from the CML (dots beneath thick line) are expected for late winter and spring due to the retreat of the CML towards the sea surface. (b) Schematic development of plankton stocks during the retreat of the convective mixed layer (CML) in spring, where the width of boxes indicates plankton concentration. Stocks emerge from a (diluted) winter stock (left) residing in a deep CML, i.e. our 'virtual euphotic layer' (diagonally striped). The stock in the shrinking CML (middle and right) is growing due to an increasing frequency of convective orbits (and increasing irradiance). The stock beneath (dotted) is considered as lost because a return to the euphotic layer (hatched) is impossible. Note: the euphotic layer in winter (hatched) may only cover a minor fraction of the virtual euphotic layer (diagonally striped). Losses due to sinking and turbulent drainage from both (growing and lost) stocks are indicated by arrows.

Longer arrows indicate total loss to abyssal darkness

that we observed in the Norwegian Sea in late winter of 1999 (Fig. 4) is very similar to the one measured during the spring bloom in May 1997 at Weathership M (i.e. 80 to $130 \mathrm{chl} \mathrm{a} \mathrm{mg} \mathrm{m}^{-2}$ ) (Irigoien et al. 1998).

\section{Loss of biomass in spring}

The schematic annual cycle of the CML (Fig. 6a) suggests that concentrations of plankton would decrease in early winter because plankton originating from the seasonal thermocline is mixed into a growing CML. Conditions would change dramatically in spring. We expect that the retreat of the CML would cause severe losses from the winter stock. The shrinking extent of orbital motions (Fig. 6a) would leave living plankton behind, losing them forever in the darkness beneath the CML. We realise that the losses caused by a changing geometry of the CML come on top of losses due to sinking and turbulent drainage. In view of these losses it is thus complicated, if not impossible, to quantify the stock which finally initiates a production in spring. In terms of integrated biomass we can only state that a production in spring originates from a rapidly diminishing winter stock. Below we will arrive at a more refined picture.

\section{Gain of biomass; shallow convection favours production}

Our coupled plankton-convection model (Backhaus et al. 1999, Wehde \& Backhaus 2000), when applied to convection layers with differing thickness (but same forcing of convection), predicted that production is inversely correlated with the extent of the CML. In a shallow CML, visits of plankton to the euphotic layer occur more often because orbital motions have a higher frequency which, apparently, favours production (Wehde 2001). This can also be inferred from our rule of thumb for the orbital time scale, $T_{\text {orb }}$. Our observations on the meridional transect (Fig. 1) appear to confirm this result: concentrations in the Norwegian Sea with shallower convection depths show notably higher values than in the Icelandic Basin (Fig. 4). In this regard we cannot exclude an influence of light conditions on observed concentrations (Fig. 4), because our estimates of incoming solar radiation (Fig. 2) indicate an increased availability of light for the second cruise, i.e. for the Norwegian Sea. We note, however, that in both regions CML depths decrease towards the south (Fig. 4), which again coincides with higher plankton concentrations. This cannot be explained by a change in available light only.

\section{The gain and loss game}

With regard to conditions in spring, our findings led us to conclude that concentrations of phytoplankton in a shrinking CML would increase, despite both heavy losses of biomass caused by the retreat, and by sinking and turbulent drainage. That is, the changing geometry of the retreating $\mathrm{CML}$, paradoxically, causes 

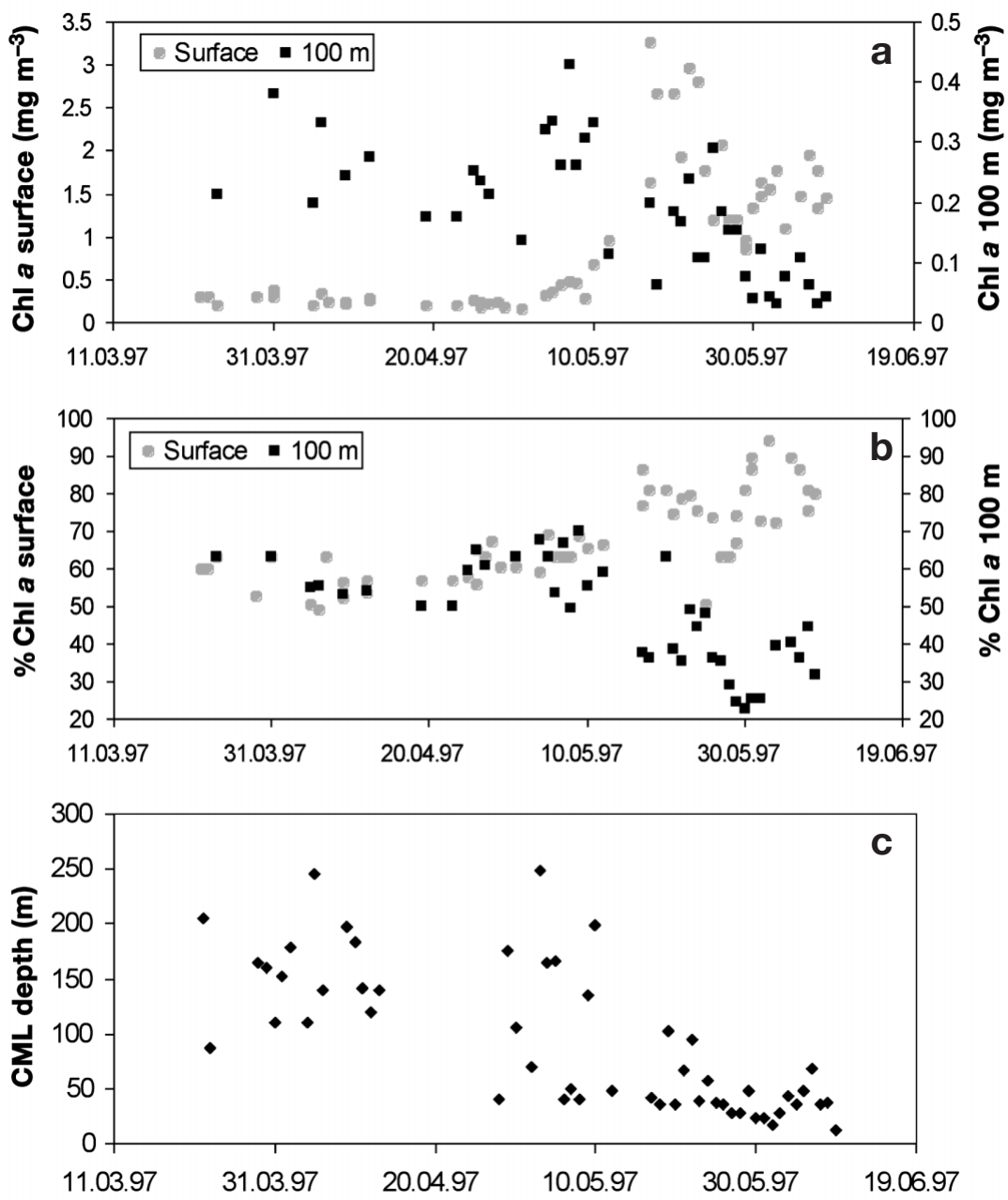

Fig. 7. (a) Concentrations of chl $a$ and (b) chl a percentage of phytoplankton near the sea surface and at a depth of $100 \mathrm{~m}$ observed at Weathership $M$ in spring 1997. Note different scales of $\mathrm{chl}$ a concentration axes for the surface and $100 \mathrm{~m}$. (c) Depth of the convective mixed layer (CML) observed at Weathership $M$ in spring 1997. The CML depth was defined by a temperature difference in excess of $0.5^{\circ} \mathrm{C}$ between CTD readings at surface and depth. For location of Weathership M see Fig. 1. Dates given as d.mo.yr.

both gains and losses. This intricate game is represented in an illustration (Fig. 6b) which qualitatively depicts the fate of 2 stocks of living plankton during the retreat of the CML. Both stocks originate from the winter stock. However, whereas the stock in the shrinking virtual euphotic layer consists of actively growing plankton, the one beneath is prone to die, for it was 'left behind'. It is beyond the reach of orbital motions and will thus remain in darkness. Note that the extent of the virtual euphotic layer (i.e. the CML) in our illustration (Fig. 6b) is always larger than the 'real' euphotic layer. It is only with an established seasonal thermocline in spring and summer (Fig. 6a) that (night-) convection, and wind mixing may cover a smaller vertical extent than Sverdrup's critical depth (Sverdrup 1953).

\section{Environmental conditions influence gain and loss}

Our observations on the meridional transect (Fig. 1) in late winter do not cover the period of retreat of the CML in spring (Fig. 6a). However, we found examples of both gain and loss in biomass that were caused by a change of the CML geometry. A secondary shallow but well mixed layer with different water mass properties appeared within the deep winter CML (Fig. 3a). In the shallow surface layer, where straight TS profiles suggest existence of convection, concentrations have more than doubled as opposed to the plankton stock beneath which was presumably 'left behind'. The reduction in salt, i.e. the added buoyancy within the surface layer, would hamper deep convection. Observations were carried out in the vicinity of severe winter showers in a large and persisting low pressure system, which suggests an influence due to horizontal advection of fresher water and/or local rainfall. The profiles of chl $a$ and water mass properties (Fig. 3a) demonstrate that changes in environmental conditions, even on a local scale, would influence the gain and loss game in biomass. Another, secondary, convection layer, though with an even less pronounced change in biomass, is also seen in Fig. 3e.

\section{Transition from CML to seasonal thermocline}

An inspection of data obtained in early 1997 at Weathership M (Irigoien et al. 1998, Dale et al. 1999) revealed interesting features in time series of phytoplankton measured near the sea surface and at a depth of $100 \mathrm{~m}$ (Fig. 7), respectively. Winter concentrations of plankton at both levels (Fig. 7a) were equal until mid May. Also the healthiness of plankton, as indicated by the chl a percentage, remained largely the same for both depths until mid May (Fig. 7b). Then, however, a rapid decay in concentration and healthiness of the stock at $100 \mathrm{~m}$ was observed. The depth of the CML (Fig. 7c), defined by a temperature difference in excess of $0.5^{\circ} \mathrm{C}$ between CTD readings at surface and depth, respectively, indicates that a seasonal thermocline was established in mid May. Daily observations from weather ship $\mathrm{M}$ were carried out only in the upper $200 \mathrm{~m}$ of the water column (Irigoien et al. 1998). Thus, CML depths in excess of $200 \mathrm{~m}$ could not be detected by a number of CTD casts. 
We explain the change in both concentration and healthiness of plankton (Fig. 7a,b), which coincided with the establishment of a seasonal thermocline (Fig. $7 \mathrm{c}$ ), by the rapid change of the CML geometry: the stock at $100 \mathrm{~m}$ was apparently 'left behind' by convective orbits. The similar concentration and percentage of chl a of plankton at both depths until mid May suggests that plankton was part of the same population, actively growing and supported by convection.

\section{Convection sets the compensation depth}

The compensation depth, according to the widely accepted theory of Sverdrup (1953), is defined by the depth where respiration equals production. The time-varying extent of the production region in winter (Fig. 6a,b), i.e. our virtual euphotic layer, suggests that the compensation depth, paradoxically, is not depth dependent (e.g. a function of available light) but a function of the convective regime (e.g. frequency of convective orbits, depth of penetration) whenever convection affects the water column. As with Sverdrup's (1953) theory, we assumed a respiration rate that was constant throughout the mixed region. Contrary to Sverdrup's theory, according to our view, production does not decrease with depth. Instead, though with low values, production remains constant throughout the mixed layer because cells at all depths have an equal chance to receive light. Below the CML there is no production, and a rapid decay of respiration rates due to dying plankton lost from the CML can be postulated. With these modifications, yet keeping the original definition of the compensation depth (Sverdrup 1953), we arrived at the schematic picture drawn in Fig. 8 for winter conditions. From this figure it is seen that the depth where respiration equals production would be given by the actual extent of the virtual euphotic layer, i.e. the CML. The actual compensation depth could readily be gauged by a CTD cast (or estimated by a mixedlayer model). However, make note that it would vary during the course of winter.

In our new description of a primary production in winter that is dominated by convection, the concept of a critical depth (Sverdrup 1953) loses its significance. The critical depth, as defined by the ratio between mixed depth $\left(Z_{\mathrm{m}}\right)$ and euphotic depth $\left(Z_{\mathrm{e}}\right)$, i.e. the depth where both vertically integrated respiration and production are equal, will always yield $Z_{\mathrm{m}} / Z_{\mathrm{e}}=1$. This is because our virtual euphotic layer and the mixed layer cover the same region in winter (Fig. 8). Sverdrup used data collected in 1949 at Weathership M (Fig. 1) to develop his well known theory (Sverdrup 1953). About half a century later observations from 'Stn Mike'

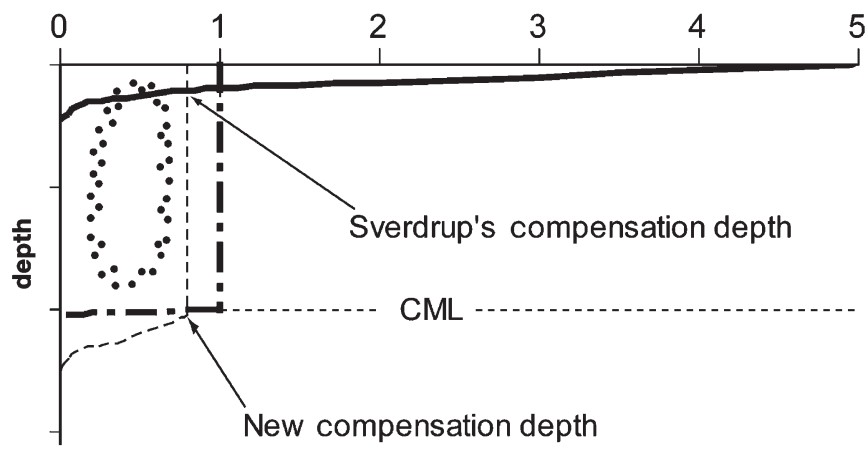

Fig. 8. Scheme of the 'new' compensation depth set by convection in winter. It is defined as the depth where respiration (thin dashed line) equals production (thick dashed and dotted line). Production however, according to our new concept, is constant throughout the convective mixed layer (CML). The 'new' compensation depth, therefore, coincides with the lower base of the CML. The 'classical' compensation depth (Sverdrup 1953), as defined from respiration and depth-, i.e. light-dependent, production in the euphotic layer (thick line), is also indicated. Upper axis: arbitrary production rates

(Weathership M, Fig. 7) helped us to produce a more refined description of primary production in winter. In noting their dwindling numbers, this highlights the importance of permanently manned stations in the open ocean.

\section{Implications}

Three implications emerge from our findings: (1) Positive net primary production is possible during winter, irrespective of the depth of the mixed layer. Production would largely depend on the characteristics of the convective regime. In this context it is interesting to note that phytoplankton cells can adapt to quite low light intensities by increasing their chl a content, and that fluctuating light with intensities below photo inhibition levels can enhance their photosynthetic efficiency (Walsh \& Legendre 1982, Kromkamp \& Limbeek 1993); (2) techniques presently applied to estimate primary production in winter are inadequate, i.e. plankton from one depth incubated at the light level measured at that depth. In fact, with time, cells far deeper than the euphotic layer will receive more light than determined by their actual position, whereas those close to the surface will receive less. That is because, statistically, all cells within the CML will eventually receive the same amount of light as a result of convective dynamics; (3) observations of phytoplankton in winter, in particular when aiming at a quantification of the biomass, should cover the water column affected by convection, i.e. the entire CML. 


\section{Distribution and composition of phytoplankton}

Quantitative estimates of phytoplankton biomass from the open ocean in winter are scarce. The few winter investigations from the Norwegian Sea (Bathman et al. 1990, Dale et al. 1999) have documented low chlorophyll values in February. However, Dale et al. (1999) report about a production occurring from February to March at Weathership M. Previous investigations revealed that diatoms typically dominate spring production in these open ocean regions. Flagellates dominating the phytoplankton biomass in winter and early spring seem to be of little relevance to spring production (Halldal 1953, Paasche 1960, Ramsfjell 1960, Paasche \& Rom 1962, Brettum 1969, Dale et al. 1999). The evolution of phytoplankton composition at Weathership M from March to June 1997 showed that the diatom Rhizosolenia delicatula, which bloomed in May, was already present in the water column in winter, though in low numbers (Irigoien et al. 1998). Diatom stocks observed along the meridional transect (Fig. 1) counted for less than $10 \%$ of the total biomass, but exhibited high species diversity. Several previously reported oceanic spring species (Halldal 1953, Paasche 1960, Paasche \& Rom 1962, Brettum 1969), such as Chaetoceros laciniosus, C. convolutus, C. decipiens, C. borealis, Rhizosolenia styliformis, Fragilariopsis cylindrus, and Pseudo-Nitzschia spp. were present in our samples. We did not observe other common, though neritic spring diatoms such as Chaetoceros debilis and Rhizosolenia fragilissima (Paasche \& Rom 1962, Brettum 1969). This indicates that our observations on the meridional transect are typical for oceanic conditions. In the Norwegian Sea, by the end of April 1999, we observed some 25 to 30 different diatom species of various concentrations as potential bloom inocula. The potential for production was confirmed by our growth experiments, which resulted in multi-species diatom growth from samples within the CML, while only flagellates grew in samples from below the CML.

Phytoplankton biomass in general was lower in the Norwegian Sea than in the North Atlantic (Fig. 4), which could be explained by the different water masses in these 2 areas: Atlantic versus a mixture of Arctic and Atlantic water. Many of the species present in the North Atlantic were not found in the Norwegian Sea. However, in the latter, several cold water species appeared which we interpret as an indication for different water masses with different growth conditions.

\section{Supporting field evidence}

Perez et al. (unpubl.), inspired by our simulations and observations (Backhaus et al. 1999, 2000), re- analysed monitoring data from late winter of 1984 obtained along a meridional transect running north from 40 to $47^{\circ} \mathrm{N}$ in the open Atlantic, off the Bay of Biscay. Their analysis not only confirms the coincidence of living phytoplankton and CML depth, but also the inverse correlation between production and convective penetration. Moreover, the comprehensive field data of Perez et al. (unpubl.) appear to prove the existence of a winter production because nutrients were partially depleted within the CML.

\section{Final conclusion}

The final, and far reaching, conclusion at which we arrived from the interpretation of our observations, was that primary production in the deep open ocean would fail in the absence of convection. This conclusion implies a change in the traditional thinking of phytoplankton ecologists.

\section{Final remarks}

To our knowledge, convection has, so far, only received little interest in investigations of the marine ecosystem. We deliberately excluded zooplankton from our discussion since we tried to focus on convection and primary production, and because our gear was not suited to catch winter zooplankton (Bathman et al. 1990). However, faecal pellets frequently found in our samples provide the suggestion that actively grazing zooplankton was present in the CML. A winter stock of phytoplankton, in fuelling energy demands of zooplankton, though facing an environment with diluted concentrations, might help to explain the presence of copepods such as Oithona spp. active during winter at high latitudes. It would also help overwintering species such as Calanus spp. to reproduce very early in the year (Irigoien et al. 1998, Niehoff et al. 1999). We also envisage an influence of orbital motions of convection on the energy budget of vertically migrating zooplankton. There are, obviously, more facets regarding the role of convection in the marine ecosystem which still await exploration.

Acknowledgements. In this investigation we made use of model components developed with partial support from both Deutsche Forschungsgemeinschaft (DFG, SFB512) and European Union, i.e. in the European Sub-Polar Ocean Projects (ESOP-1 and -2) and the CONVECTION project (MAS2CT93-0057, MAS3-CT95-0015, EVK2-2000-00544). Shiptime of RV 'Valdivia' was provided by the University of Hamburg. We greatly acknowledge the help of Jennifer Verduin, who carefully edited our manuscript, and of Norbert Verch, who prepared our illustrations. We very much appreciate, and herewith acknowledge, the constructive criticism we received from 2 anonymous reviewers. 


\section{LITERATURE CITED}

Anderson TR (1993) A spectrally averaged model of light penetration and photosynthesis. Limnol Oceanogr 38: 1403-1419

Backhaus JO, Kämpf J (1999) Simulations of sub-mesoscale oceanic convection and ice-ocean interactions in the Greenland Sea. Deep Sea Res II 46(6-7):1427-1456

Backhaus JO, Wehde H (1997) Convection in the Baltic Sea a numerical process study. In: Ozsoy E, Mikaelyan A (eds) NATO ASI-series: sensitivity to change: Black Sea, Baltic Sea and North Sea. Kluwer Academic Publishers, Dordrecht, p 295-309

Backhaus JO, Fohrmann H, Kämpf J, Rubino A (1997) Formation and export of water masses produced in Arctic shelf polynyas: process studies of oceanic convection. ICES J Mar Sci 54:366-382

Backhaus J, Wehde H, Hegseth EN, Kämpf J (1999) 'Phytoconvection'- on the role of oceanic convection in primary production. Mar Ecol Prog Ser 189:77-92

Backhaus JO, Hegseth EN, Wehde H, Hatten K, Logemann K, Nedderhut H, Arndt A (2000) Cruise Report 'Phytoconvection'. Valdivia Cruises \#176 and 178. Tech Rep 1-99, Institut für Meereskunde, Zentrum für Meeres- und Klimaforschung, University of Hamburg

Bathman UV, Noji TT, von Bodungen B (1990) Copepod grazing potential in late winter in the Norwegian Sea-a factor in the control of spring phytoplankton growth? Mar Ecol Prog Ser 60:225-233

Billett DS, Lampitt RS, Rice AL, Mantoura RFC (1983) Seasonal sedimentation of phytoplankton to the deep-sea benthos. Nature 302:520-522

Brettum P (1969) En undersøkelse over fytoplanktonet på værskip-posisjonene 'A' og 'M' i Nord-Atlanteren, 0-1000 m. MS thesis, University of Oslo

Dale T, Rey F, Heimdal BR (1999) Seasonal development of phytoplankton at a high latitude ocean site. Sarsia 84:1-17

Ducklow HW, Harris RP (1993) Introduction to the JGOFS North Atlantic Bloom Experiment. In: Ducklow HW, Harris RP (eds) JGOFS: The North Atlantic Bloom Experiment. Deep-Sea Res II 40(1/2):1-8

Halldal P (1953) Phytoplankton investigations from the weather ship M in the Norwegian Sea. Hvalråd Skr 38:1-91

Hegseth EN, Svendsen H, von Quillfeldt CH (1995) Phytoplankton in fjords and coastal waters of northern Norway: environmental conditions and dynamics of the spring bloom. In: Skjoldal HR, Hopkins C, Erikstad KE, Leinaas HP (eds) Ecology of fjords and coastal waters. Elsevier Science, Amsterdam, p 45-72

Holm-Hansen O, Riemann B (1978) Chlorophyll a determination: improvements in methodology. Oikos 30:438-447

Huisman J, van Oostveen P, Weissing FJ (1999) Critical depth and critical turbulence: two different mechanisms for the development of phytoplankton blooms. Limnol Oceanogr 44:1781-1787

Huisman J, Arrayas M, Ebert U, Sommeijer B (2002) How do sinking phytoplankon species manage to persist? Am Nat 159(3):245-254

Irigoien X, Head R, Klenke U, Meyer-Harms B, Harbour D, Niehoff B, Hirche HJ, Harris R (1998) A high frequency time series at Weathership $M$, Norwegian Sea, during the 1997 spring bloom: feeding of adult female Calanus finmarchicus. Mar Ecol Prog Ser 172:127-137

Kämpf J, Backhaus JO (1998) Shallow brine driven free convection in polar oceans: non-hydrostatic numerical process studies. J Geophys Res 103(C3):5577-5593

Kämpf J, Backhaus JO (1999) Ice ocean interactions during shallow convection under conditions of steady winds: 3-D numerical studies. Deep-Sea Res II 46(6-7)1335-1355

Kromkamp J, Limbeek M (1993) Effect of short-term variation in irradiance on light harvesting and photosynthesis of the marine diatom Skeletonema costatum: a laboratory study simulating vertical mixing. J Gen Microbiol 139:2277-2284

Marshall J, Schott F (1999) Open-ocean convection: observations, theory and models. Rev Geophys 37:1-64

Marshall SM, Orr AP (1928) The photosynthesis of diatom cultures in the sea. J Mar Biol Assoc UK 15:321-364

McCartney MS, Talley LD (1982) The subpolar mode water in the North Atlantic Ocean. J Phys Oceanogr 12:1169-1188

Niehoff B, Klenke U, Hirche HJ, Irigoien X, Head R, Harris R (1999) A high frequency time series at Weathership $M_{\text {, }}$ Norwegian Sea, during the 1997 spring bloom: the reproductive biology of Calanus finmarchicus. Mar Ecol Prog Ser 176:81-92

Paasche E (1960) Phytoplankton distribution in the Norwegian Sea in June, 1954, related to hydrography and compared with primary production data. Fiskeridir Skr Ser Havunders 12(11):1-77

Paasche E, Rom AM (1962) On the phytoplankton vegetation of the Norwegian Sea in May 1958. Nytt Mag Bot 9:33-60

Passow U (1991) Species-specific sedimentation and sinking velocities of diatoms. Mar Biol 108:449-455

Paulsen O (1904) Plankton investigations in the waters around Iceland in 1903. Medd Komm Havundersøg Kobenhavn Ser Plankton 1(3):1-78

Paulsen O (1918) Plankton and other biological investigations in the sea around the Færoes in 1913. Medd Komm Havundersøg Kobenhavn Ser Plankton 1(5):1-43

Platt T, Subba Rao DV, Smith JC, Li WK, Irwin B, Horne ERW, Sameoto DD (1983) Photosynthetically competent phytoplankton from the aphotic zone of the deep ocean. Mar Ecol Prog Ser 10:105-110

Platt T, Sathyendranath S, Ravindran P (1990) Primary production by phytoplankton: analytic solutions for daily rates per unit area of water surface. Proc R Soc Lond B 241: 101-111

Ramsfjell E (1960) Phytoplankton distribution in the Norwegian Sea in June, 1952 and 1953. Fiskeridir Skr Ser Havunders 12(10):1-112

Reid PC (1977) Continuous plankton records: changes in the composition and abundance of the phytoplankton of the North-Eastern Atlantic Ocean and North Sea, 1958-1974. Mar Biol 40:337-339

Robinson GA (1970) Continuous plankton recors: variation in the seasonal cycles of phytoplankton in the North Atlantic. Bull Mar Ecol 6:333-345

Roy S, Legendre L (1979) DCMU-enhanced fluorescence as an index of photosynthtic activity in phytoplankton. Mar Biol 55:93-101

Smayda T (1970) The suspension and sinking of phytoplankton in the sea. Oceanogr Mar Biol Annu Rev 8:353-414

Steemann Nielsen E (1935) The production of phytoplankton at the Faroe Isles, Iceland, East Greenland and in the waters around. Medd Komm Havundersøg Kobenhavn Ser Plankton 3(1):1-93

Steemann Nielsen E (1943) Über das Frühlingsplankton bei Island und den Faröer-Inseln. Medd Komm Havundersøg Kobenhavn Ser Plankton 3(6):1-14

Sverdrup HU (1953) On conditions for the vernal blooming of phytoplankton. J Cons Int Explor Mer 18:287-295

Townsend DW, Cammen LM, Holligan PM, Campbell DE, Pettigrew NR (1994) Causes and concsequences of variability in the timing of spring phytoplankton blooms. Deep-Sea Res 41:747-765 
Turner JS (1973) Buoyancy effects in fluids. Cambridge University Press

Utermöhl H (1931) Neue Wege in der quantitativen Erfassung des Planktons. Mitt Int Ver Limnol 5:567-596

Utermöhl H (1958) Zur Vervollkommnung der quantitativen Phytoplankton-Methodik. Mitt Int Ver Limnol 9: 1-39

van Aken HM, Becker G (1996) Hydrography and throughflow in the north eastern North Atlantic Ocean: the NANSEN project. Prog Oceanogr 18:297-346

von Bodungen B, von Bröckel K, Smetacek V, Zeitschel B (1981) Growth and sedimentation of the phytoplankton

Editorial responsibility: Otto Kinne (Editor),

Oldendorf/Luhe, Germany spring bloom in the Bornholm Sea (Baltic Sea). Kiel Meeresforsch Sonderh 5:49-60

Walsh P, Legendre L (1982) Effets des fluctuations rapides de la lumiere sur la photosynthese du phytoplancton. J Plankton Res 4:313-327

Wehde H (2001) Phytokonvektion im offenen Ozean; Feldexperimente und numerische Prozessstudien. ZMK Hamburg, Reihe B: 38

Wehde H, Backhaus JO (2000) The fate of Lagrangian tracers in oceanic convective conditions: on the influence of oceanic convection in primary production. Nonlinear Analysis: Real World Applications 1:3-21

Submitted: May 16, 2001; Accepted: October 15, 2002

Proofs received from author(s): March 11, 2003 